NASA/TM-2002-211731

ARL-TR-2734
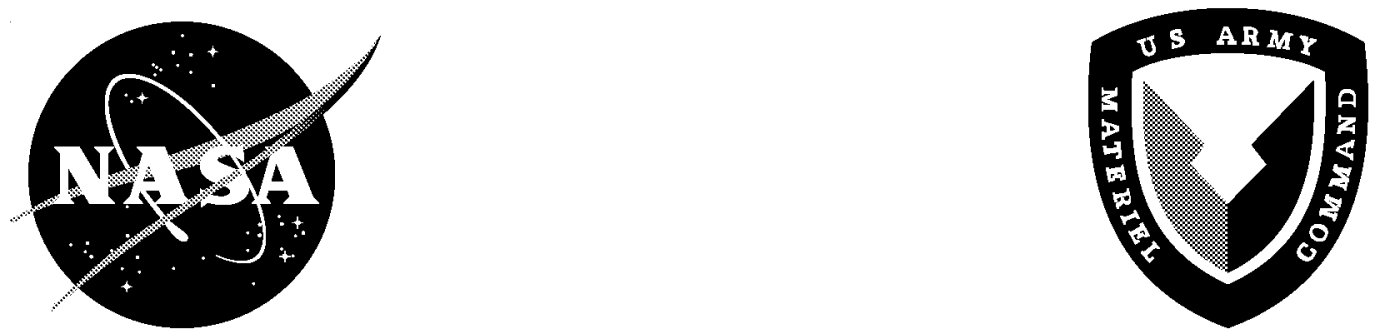

Impact Testing and Simulation of a Crashworthy Composite Fuselage Section With Energy-Absorbing Seats and Dummies

Edwin L. Fasanella

U. S. Army Research Laboratory

Vehicle Technology Directorate

Langley Research Center, Hampton, Virginia

Karen E. Jackson

U. S. Army Research Laboratory

Vehicle Technology Directorate

Langley Research Center, Hampton, Virginia 


\section{The NASA STI Program Office ... in Profile}

Since its founding, NASA has been dedicated to the advancement of aeronautics and space science. The NASA Scientific and Technical Information (STI) Program Office plays a key part in helping NASA maintain this important role.

The NASA STI Program Office is operated by Langley Research Center, the lead center for NASA's scientific and technical information. The NASA STI Program Office provides access to the NASA STI Database, the largest collection of aeronautical and space science STI in the world. The Program Office is also NASA's institutional mechanism for disseminating the results of its research and development activities. These results are published by NASA in the NASA STI Report Series, which includes the following report types:

- TECHNICAL PUBLICATION. Reports of completed research or a major significant phase of research that present the results of NASA programs and include extensive data or theoretical analysis. Includes compilations of significant scientific and technical data and information deemed to be of continuing reference value. NASA counterpart of peer-reviewed formal professional papers, but having less stringent limitations on manuscript length and extent of graphic presentations.

- TECHNICAL MEMORANDUM. Scientific and technical findings that are preliminary or of specialized interest, e.g., quick release reports, working papers, and bibliographies that contain minimal annotation. Does not contain extensive analysis.

- CONTRACTOR REPORT. Scientific and technical findings by NASA-sponsored contractors and grantees.
- CONFERENCE PUBLICATION. Collected papers from scientific and technical conferences, symposia, seminars, or other meetings sponsored or co-sponsored by NASA.

- SPECIAL PUBLICATION. Scientific, technical, or historical information from NASA programs, projects, and missions, often concerned with subjects having substantial public interest.

- TECHNICAL TRANSLATION. Englishlanguage translations of foreign scientific and technical material pertinent to NASA's mission.

Specialized services that complement the STI Program Office's diverse offerings include creating custom thesauri, building customized databases, organizing and publishing research results ... even providing videos.

For more information about the NASA STI Program Office, see the following:

- Access the NASA STI Program Home Page at http://www.sti.nasa.gov

- E-mail your question via the Internet to help@sti.nasa.gov

- Fax your question to the NASA STI Help Desk at (301) 621-0134

- Phone the NASA STI Help Desk at (301) 621-0390

- Write to:

NASA STI Help Desk

NASA Center for AeroSpace Information

7121 Standard Drive Hanover, MD 21076-1320 
NASA/TM-2002-211731

ARL-TR-2734
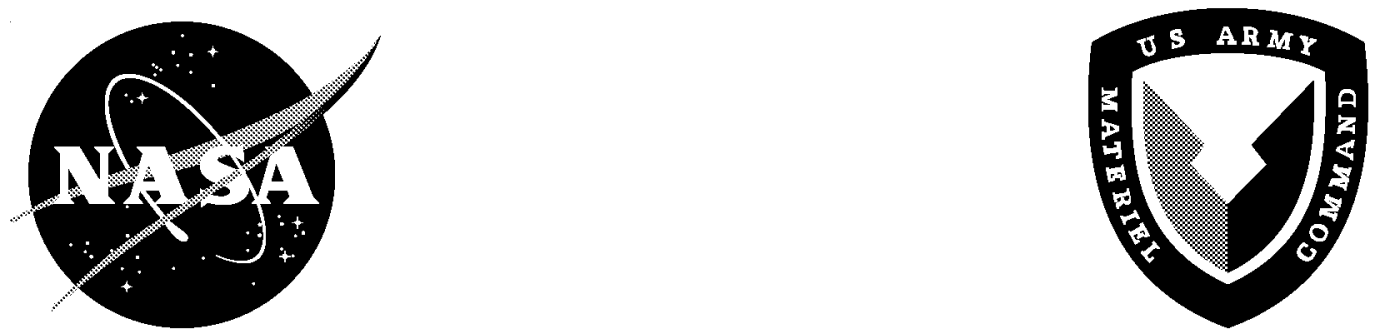

Impact Testing and Simulation of a Crashworthy Composite Fuselage Section With Energy-Absorbing Seats and Dummies

Edwin L. Fasanella

U. S. Army Research Laboratory

Vehicle Technology Directorate

Langley Research Center, Hampton, Virginia

Karen E. Jackson

U. S. Army Research Laboratory

Vehicle Technology Directorate

Langley Research Center, Hampton, Virginia

National Aeronautics and

Space Administration

Langley Research Center

Hampton, Virginia 23681-2199

June 2002 
The use of trademarks or names of manufacturers in the report is for accurate reporting and does not constitute an official endorsement, either expressed or implied, of such products or manufacturers by the National Aeronautics and Space Administration or the U.S. Army.

Available from:

NASA Center for AeroSpace Information (CASI) 7121 Standard Drive

Hanover, MD 21076-1320

(301) 621-0390
National Technical Information Service (NTIS) 5285 Port Royal Road

Springfield, VA 22161-2171

(703) 605-6000 


\title{
Impact Testing and Simulation of a Crashworthy Composite Fuselage Section with Energy-Absorbing Seats and Dummies
}

\author{
Edwin L. Fasanella and Karen E. Jackson \\ e.1 hasanela@larymasa.gov, k.e.jackson@larc.nasa.gov \\ US Army Research Laboratory, Vehicle Technology Directorate \\ Hampton, Virginia
}

\begin{abstract}

\section{Introduction}

A research program was conducted at NASA Langley Research Center to develop an innovative and cost-effective crashworthy fuselage concept for light aireraft and rotorcraft [1-3]. The composite fuselage concept was designed to meet structural and flight-load requirements and to provide improved crash protection. The two primary design goals for crashworthiness are to limit the impact forces transmitted to the occupants, and to maintain the structural integrity of the fuselage to ensure a minimum safe occupant volume. To meet these objectives, an aircraft or rotorcraft fuselage must be designed for high stiffness and strength to prevent structural collapse during a crash. Yet, the fuselage design must not be so stiff that it transmits or amplifies high impact loads to the occupants. Ideally, the design should contain some crushable elements to help limit the loads transmitted to the occupant to survivable or non-injurious levels.
\end{abstract}

A $25-\mathrm{ft} / \mathrm{s}$ vertical drop test of a composite fuselage section was conducted with two energy-absorbing seats occupied by anthropomorphic dummies to evaluate the crashworthy features of the fuselage section and to determine its interaction with the seats and dummies. The 5-ft. diameter fuselage section consists of a stiff structural floor and an energy-absorbing subfloor constructed of Rohacel foam blocks. The experimental data from this test were analyzed and correlated with predictions from a crash simulation developed using the nonlinear, explicit transient dynamic computer code, MSC.Dytran. The anthropomorphic dummies were simulated using the Articulated Total Body (ATB) code, which is integrated into MSC.Dytran.

The fuselage concept, shown in Figure 1, consists of a stiff upper fuselage, a structural floor, and an energyabsorbing subfloor. The upper section of the fuselage cabin is fabricated using a composite sandwich construction and is designed to provide a protective shell that encloses the occupants in the event of a crash. The energy-absorbing subfloor is designed to dissipate kinetic energy through stable crushing. Finally, a key feature of the fuselage concept is the stiff structural floor. The structural floor is designed to react the loads generated by crushing of the subfloor, and to provide a stable platform for seat and restraint attachment.

During the first year of the research program, a 12-in. diameter, 1/5-scale model composite fuselage was designed, fabricated, and tested to verify structural and flight-load requirements [3]. During the second year of the research program, energy-absorbing subfloor configurations were evaluated using quasi-static testing and finite element simulation to determine the best design for use in the $1 / 5$-scale model fuselage concept $[4,5]$. During the third year of the program, a full-scale version of the fuselage concept was fabricated, and a vertical drop test was conducted to validate the scaling process [6]. Test, analysis, and correlation with finite element models were performed for each test in the series. For the 1/5- and early full-scale drop tests, the inertial loading that normally would be provided by seats and occupants was represented with lead weights. In April 2001, a full-scale fuselage section was tested with two energy-absorbing seats, each with an anthropomorphic dummy occupant. The objective of the drop test was to demonstrate the crashworthiness of the fuselage concept for a more realistic loading environment using seats and dummies. The data from the drop test and the development of an integrated crash simulation are the focus of this paper.

Since the completion of the initial research, the composite fuselage section has been used as a test bed for conducting other crash-related experiments. In 2000, two drop tests of a composite fuselage section were performed for the specific goal of examining test and analysis correlation approaches for detailed finite element crash simulations [7]. One test was performed from a drop height of 1.75 inches to excite the linear frequency response, and test data were correlated with an MSC.Nastran analysis. The second test was performed for an impact velocity of 25 $\mathrm{ft} / \mathrm{s}$, and the test data were correlated with a nonlinear, transient dynamic crash simulation. For both tests, the fuselage section was loaded symmetrically using lead masses that were attached to the floor through seat tracks. The total floor mass was approximately $1000 \mathrm{lbs}$. The 25 $\mathrm{ft} / \mathrm{s}$ impact test described in Ref. 7 is of particular interest because it was performed at the same initial vertical velocity as the fuselage test with seats and dummies described in this paper. In addition, the fuselage section described in Ref. 7 had nearly the same floor loading; however, only lead masses were attached to the floor in that test. 
In addition, the fuselage section is currently being used as a test bed to evaluate the influence of impact surface on dynamic structural response. To date, drop tests of the composite fuselage section with lead floor masses have been performed on rigid and soft soil surfaces [8]. A drop test into water is planned for Spring 2002. During each test, a new fuselage section was impacted at the same drop height and with the same floor loading provided with lead masses.

The objectives of the present paper are to describe: (1) the $25-\mathrm{ft} / \mathrm{s}$ vertical drop test of the composite fuselage section with seats and dummies conducted in April 2001 and the interaction of the crashworthy fuselage concept with the dummy occupants, and (2) the correlation between test data and analytical predictions from an integrated MSC.Dytran [9] and Articulated Total Body (ATB) [10] model of the fuselage section, seats, and dummies.

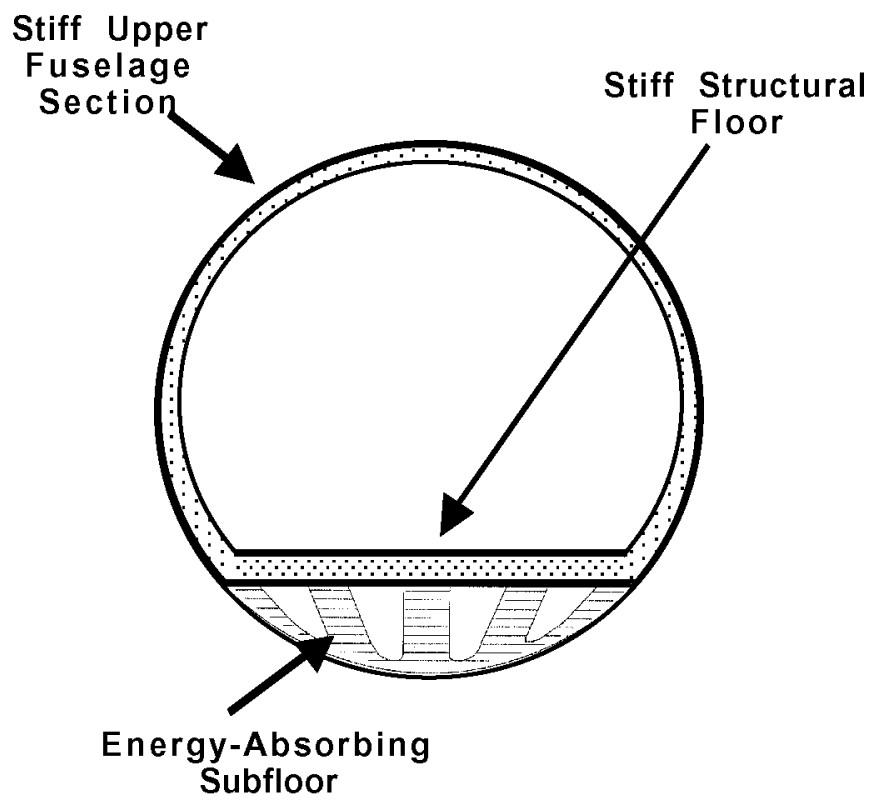

Fig. 1. Schematic drawing of the fuselage concept.

\section{Test Program}

The fuselage section is 5-ft. in diameter and is approximately 5 -ft in length. The upper section of the fuselage is fabricated using a composite sandwich construction with a $3-\mathrm{lb} / \mathrm{ft}^{3}$ closed cell polyurethane foam core and $\mathrm{E}-$ glass/epoxy fabric face sheets. E-glass/epoxy material was chosen because of its low cost and wide use by the light aircraft industry. In addition, a room temperature cure epoxy system was selected, thus eliminating the need for a more expensive autoclave cure. The composite sandwich construction in the floor of the fuselage consists of an $8-\mathrm{lb} / \mathrm{ft}^{3}$ closed-cell polyurethane foam core with hybrid face sheets consisting of E-glass/epoxy and graphite/epoxy composite fabric. The layers of graphite/epoxy fabric were added for increased stiffness and improved structural rigidity. The energy-absorbing subfloor configuration is a geometric foam-block design, consisting of five, 6.5-inch deep uniformly spaced, individual blocks of a crushable Rohacell 31-IG (Industrial Grade) 2.8-lb/ $\mathrm{ft}^{3}$ closed-cell foam overlaid with E-glass/epoxy face sheets. The geometry of the foam blocks, shown in Figure 1, was chosen to maintain a fairly uniform cross-sectional area as the crush zone develops and progresses vertically, resulting in a fairly constant crushing force. Details of the composite fuselage section design and fabrication can be found in Reference 6.

A plan-view of the floor is shown in Figure 2 that indicates the location of the seats, lead masses, dummy feet, and accelerometers used for test/analysis correlation. Preand post-test photographs of the fuselage section with dummy occupants are shown in Figure 3. The empty section weighed $200 \mathrm{lbs}$. Lead blocks were placed on the floor to bring the total section weight, including the seats and dummies, to 1,243 pounds. The fuselage section, seats, and dummies were instrumented with 80 transducers to record the dynamic response of the impact. The fuselage section was raised to a height of 10 feet and dropped onto a rigid surface to achieve an impact velocity of approximately $25 \mathrm{ft} / \mathrm{s}$. The data were recorded at 10,000 samples/second using an on-board digital data acquisition system. The $50^{\text {th }}$ percentile male Hybrid II dummies had lumbar load cells installed to measure the spinal force response. In addition, load cells were placed under each seat leg, and accelerometers were placed on the floor and circumferentially around the fuselage. Each test dummy was secured in his seat with a conventional lap belt and shoulder harness. Each dummy was instrumented with 9 accelerometers, three in the head, chest, and pelvis to record accelerations in the forward, side, and vertical directions.

The energy-absorbing seats used in the test were Jungle Aviation And Radio Service (JAARS) seats, which consist of a steel tubular frame with an S-shaped front leg (see Figure 4). The development of the JAARS seat concept began in the 1980's. Prior to in-service use, prototype JAARS seats were tested in dynamic sled tests and in full-scale crash tests of general aviation aircraft at the Impact Dynamics Research Facility located at NASA Langley Research Center [11].

\section{Finite Element Model}

MSC.Dytran, a general-purpose explicit nonlinear transient dynamic finite element code, was used to model the composite fuselage section and the JAARS seats. The $50^{\text {th }}$ percentile male Hybrid II anthropomorphic dummies were modeled using the ATB code. ATB is an independent computer code developed by the Air Force Wright Laboratory as a numerical dummy model, and it is integrated within the MSC.Dytran program. The ATB dummy model consists of hinged segments with inertias, joint properties, and contact surfaces defined to represent a Hybrid II dummy. A picture of the integrated 
MSC.Dytran model of the fuselage section with two JAARS seats and two seated ATB dummies is shown in Figure 5a, and a cut-away view of the right half of the model is shown in Figure 5b. The MSC.Dytran model of the 4130 annealed steel seat frames, shown in Figure 5c using MSC.Patran's 3-D visualization, were modeled with beam elements, which were defined with elasticplastic material properties. The modulus of the steel was $2.97 \mathrm{e} 07 \mathrm{psi}$, the yield stress was estimated to be 5.2e04 psi, and a strain hardening modulus of $1.0 \mathrm{e} 06$ psi was assumed. The ATB dummy segments are covered with rigid shell elements in MSC.Dytran to provide the correct body contour needed for contact calculations. The seat cushion forces were modeled in ATB using three linear force-deflection segments. Each dummy model consisted of 3,069 nodes and 3,207 elements.

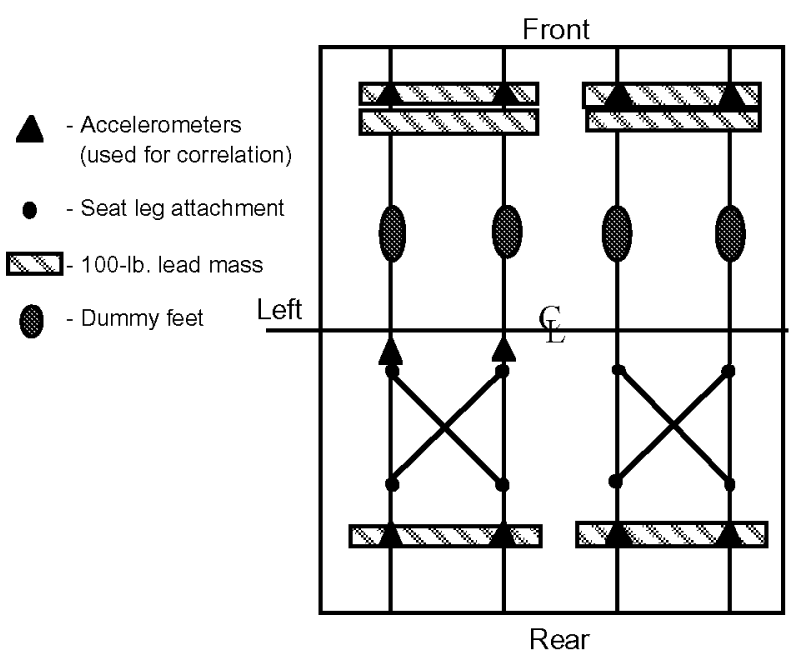

Fig. 2. Floor layout of the seats, dummies, instrumentation and ballast weight.

A three-dimensional finite element model of the full-scale fuselage was developed using the pre-processing software, MSC.Patran. The model was executed in MSC.Dytran Intel Linux Version 2001. Excluding the dummies, the complete section model consists of 27,408 nodes and 32,811 elements. The elements in the fuselage section structure included 13,317 shell elements, 18,796 solid elements; 698 beam elements representing the seats and seat rails, and 48 concentrated masses representing the lead floor masses and ballast weights. The inner and outer face sheets of the upper section and floor were modeled using 4-noded Belytschko-Lin-Tsay shell elements, and the foam core in the upper section, floor, and subfloor was represented by 8-noded hexagonal solid elements. Contact regions were defined between the section and the impact surface, between the seat and the floor, between the dummy and the seat cushions, and between the dummy's feet and the floor.

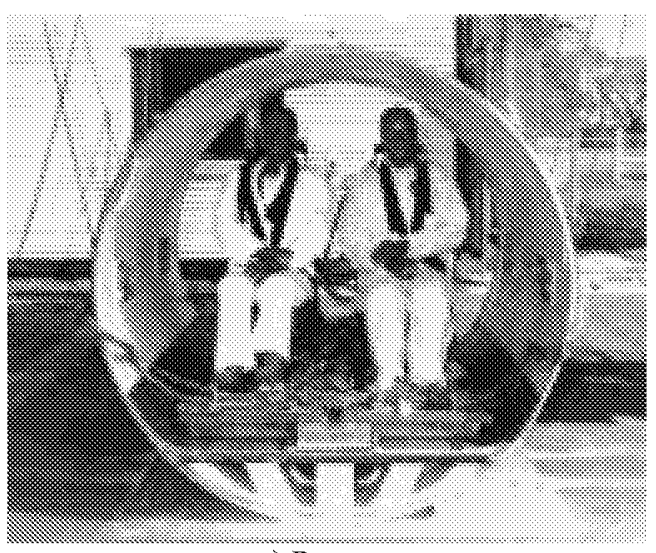

a) Pre-test.

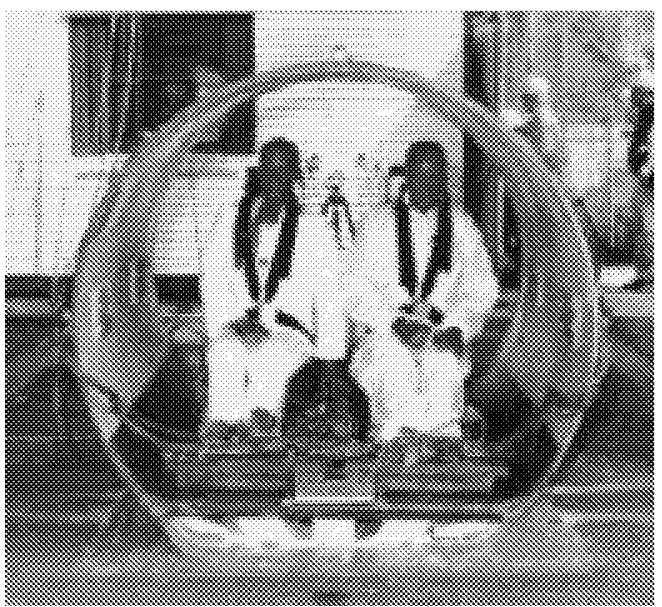

b) Post-test.

Fig. 3. Photographs of the fuselage sections with energyabsorbing seats and dummy occupants.

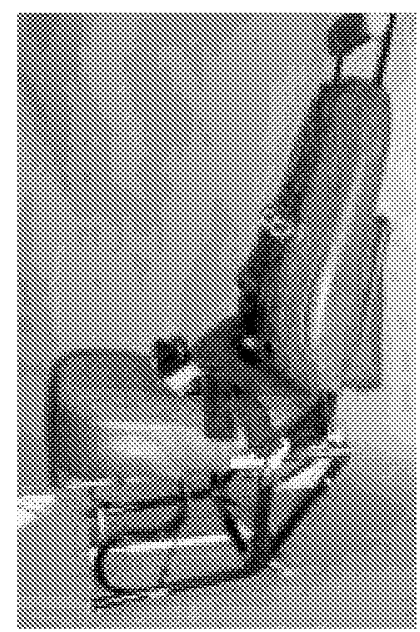

Fig. 4. Photograph of a JAARS seat. 


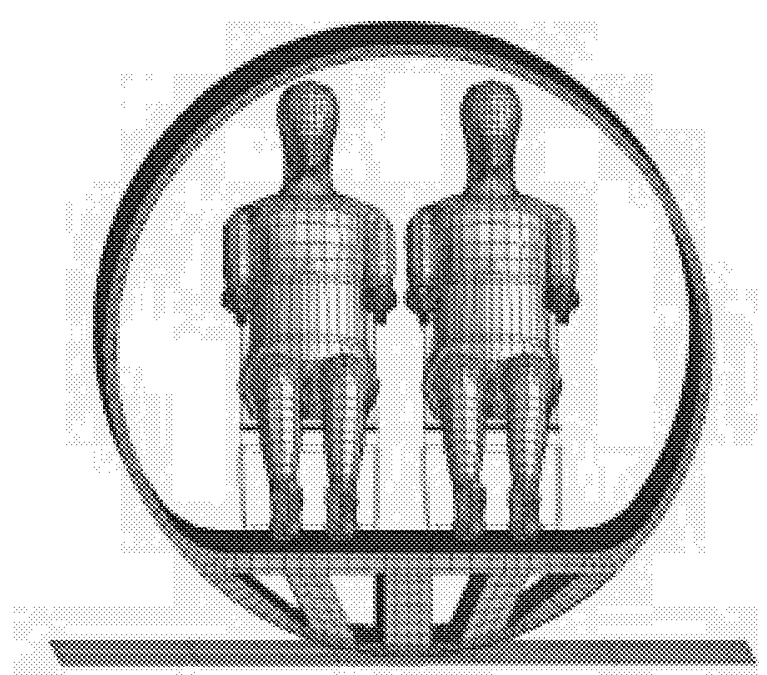

(a) Front view - full model.

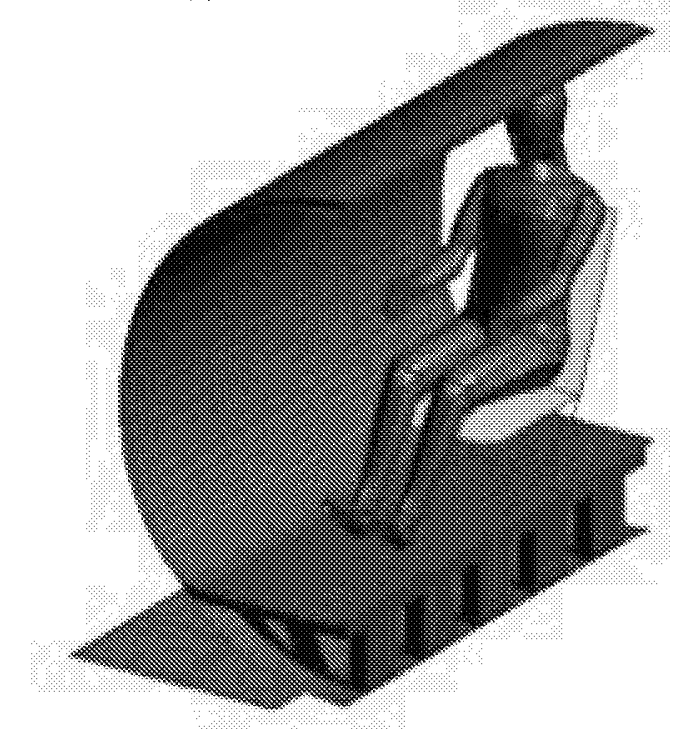

(b) One-half cut of the model.

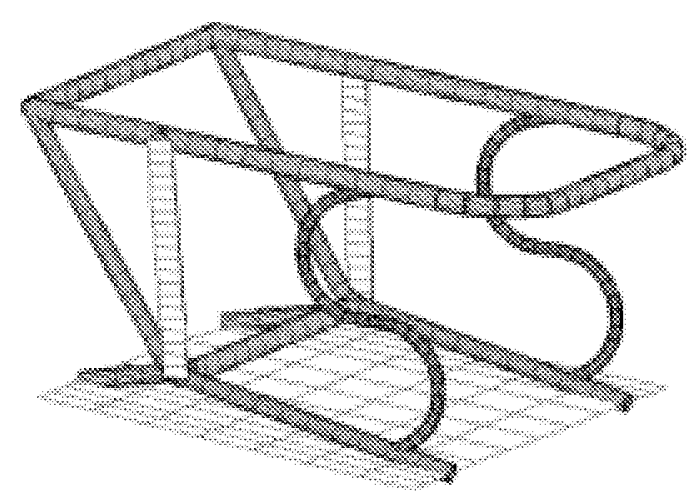

(c) Seat frame mode1, with 3-D beam visualization.

Fig. 5. Pre-test finite element model.
The material properties of the E-glass/epoxy fabric material were determined from coupon tests and are modeled using a bilinear elastic-plastic material model with strain hardening. The $3-$ and $8-1 \mathrm{~b} / \mathrm{ft}^{3}$ polyurethane foam cores in the upper section and floor were modeled as linear elastic solid materials. The more complicated multi-layered face sheets in the floor were modeled as laminated composite shell elements (PCOMP) in MSC.Dytran. The material model for the five 6.5-in.-deep Rohacell foam blocks, which are located in the subfloor region of the finite element model, were obtained from crushing tests of individual cubic blocks of foam. The Rohacell was represented as crushable foam (FOAM2) with the stress-strain response provided in a "look-up" table. The table was determined directly from the experimental data, and stress values were provided versus volumetric crush. The bulk modulus of the Rohacell foam is based on the maximum slope of the stress-strain response to provide for numerical stability. The FOAM2 material model is used in MSC.Dytran for a crushable, isotropic foam material with a user-specified hysteresis response for unloading and a Poisson's ratio that is effectively zero. An exponential unloading curve and a 74.2-psi tensile cutoff stress were specified in the current model, as shown in Figure 6. The energy dissipation factor in FOAM2 was set to 0.99.

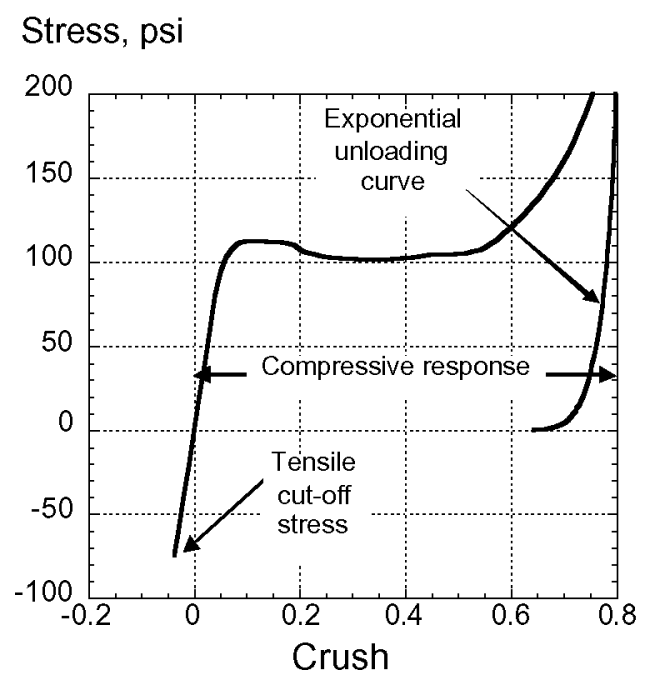

Fig. 6. Quasi-static crushing response of Rohacell foam.

A master-surface to slave-node contact is defined between the subfloor and the impact surface, which is modeled as a thick plate with all of the edge nodes fixed. The initial one-degree nose down pitch of the fuselage was not modeled. An initial vertical velocity of $300 \mathrm{in} / \mathrm{s}(25 \mathrm{ft} / \mathrm{s})$ is assigned to all nodes in the model except for those nodes forming the impact surface. More details on the structural model of the fuselage can be found in References [6,7]. The model was run on one processor of an Intel Linux two-processor, $1.7 \mathrm{GHz}$ workstation. To simulate 0.07 seconds required about 5.5 CPU hours. 


\section{Experimental Results}

Velocity data obtained from integrating acceleration responses are often useful in understanding the motion of the test article and in providing a check on the validity of the acceleration data. In Figure 7, four velocities on the left side of the fuselage are compared. Three velocities were computed from data obtained from accelerometers at the floor level from the front to the rear on the left hand side. The fourth velocity, which goes to zero more slowly, was computed for the left dummy pelvis. As observed from motion picture data, the front of the section was pitched downward about 1 degree at impact. However, symmetry of the data about the centerline was reasonable, so only one side will be examined in detail. Included are the outboard seat track locations for the left front mass, which is 8 inches from the front edge; the left rear mass, which is 8 inches from the rear edge; and the left front seat leg, which is 4 inches behind the center-line of the section (see Fig. 2). In addition, the velocity of the pelvis of the left dummy is shown for comparison and completeness. The front and rear velocities were computed from data obtained from accelerometers located on 100 pound lead masses, while the acceleration at the seat leg was not associated with a large mass. From Figure 7, it is apparent that the rear mass slows down more quickly than the front mass. The velocity of the rear mass crosses zero at time 0.03 seconds and then changes direction; i.e., rebounds. The velocity of the front mass does not cross zero until 0.035 seconds.

Since the fuselage section was initially balanced and the front bottom edge hit first, these results may be at first counter-intuitive. The explanation of this behavior is that the mass of the dummy is initially uncoupled from the floor through the deforming seat. Thus, since the dummy mass is initially uncoupled, there is less apparent mass acting on the floor at the rear. Consequently the acceleration of the rear floor is greater, and thus it stops more quickly. The velocity of the floor near the front left outboard seat leg crosses zero just a few milliseconds after the rear mass. Note that the dummy velocity does not go to zero until 0.055 seconds. The energy-absorbing seat, or to be more exact, the force limiting seat, allows the dummy to stop over a larger distance, reducing the acceleration to the occupant.

Next, the front and rear vertical floor accelerations for the outboard and inboard rail positions are compared in Figures 8 and 9 , respectively. The accelerometer data in the plots were filtered with a $180-\mathrm{Hz}$ low-pass digital Butterworth filter passed forward and then backward in time to eliminate any phase shift. As expected after viewing the velocity plot, the rear acceleration peaks are higher for both the inboard and outboard positions. However, the rear inboard acceleration is only slightly higher than the front inboard acceleration. Also, the initial inboard acceleration peak is considerably higher than the respective outboard acceleration. This response occurs as the ground contact force is initially applied at the center, or inboard locations.

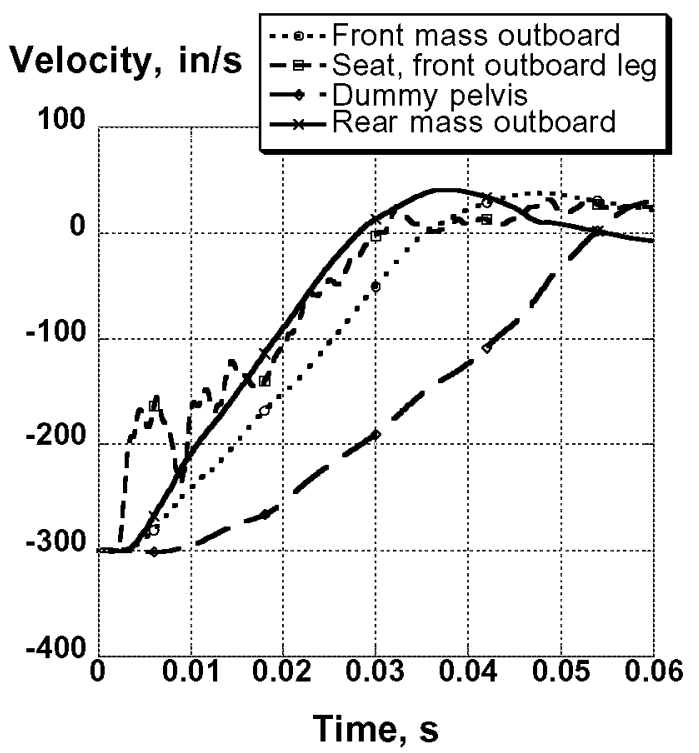

Fig. 7. Velocities on the left side of the fuselage, including the outboard seat track location of the front mass, rear mass, the front seat leg, and the dummy pelvis.

Acceleration, $\mathbf{g}$

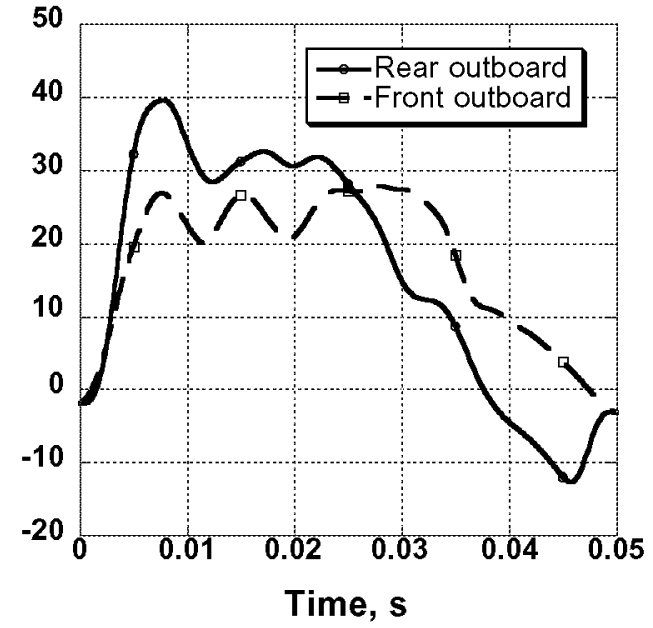

Fig. 8. Comparison of filtered floor accelerations at left front outboard rail position with left rear outboard.

The vertical acceleration time-histories from the left dummy pelvis and the inboard and outboard seat track accelerometers on the rear lead mass just behind the left seat are plotted in Figure 10. Note that the floor acceleration pulse duration is approximately $0.035-0.04$ seconds. The onset of the dummy pelvis acceleration lagged the onset of floor acceleration by approximately 0.005 seconds, and the duration of the pelvis acceleration is about $50 \%$ longer than the floor acceleration. The floor acceleration initially peaks around 40 to $50 \mathrm{-g}$ and then levels off between 30 and $35-\mathrm{g}$. The stroking of the en- 
ergy-absorbing seat lengthens the width of the pelvis acceleration pulse and lowers the effective acceleration of the dummy pelvis to below 20 -g except for the localized peak of 30 -g that occurs near 0.047 seconds. As can be seen in Figure 11, the acceleration responses of the right dummy pelvis and floor show similar trends. The inboard floor accelerometer in Figure 11 lost data shortly after 0.035 seconds. The outboard accelerometer lost data early into the impact and is not shown. The effect of the $180-\mathrm{Hz}$ filter on the dummy acceleration can be determined by comparing the raw dummy pelvis acceleration shown in Figure 12 with the filtered pelvis acceleration shown in Figure 11. The $180-\mathrm{Hz}$ low-pass filter only removes the high frequency noise and ringing from the dummy pelvis accelerometer data.

Acceleration, $\mathbf{g}$

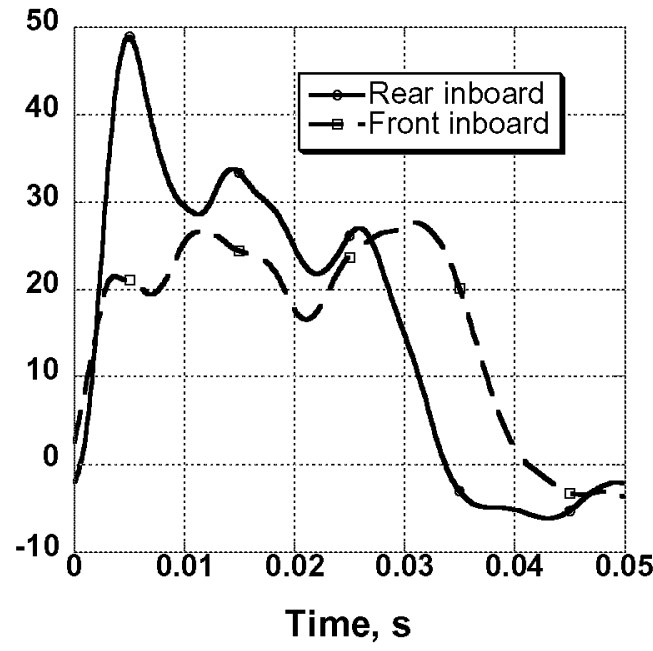

Fig. 9. Comparison of filtered floor accelerations at left front inboard rail position with left rear inboard.

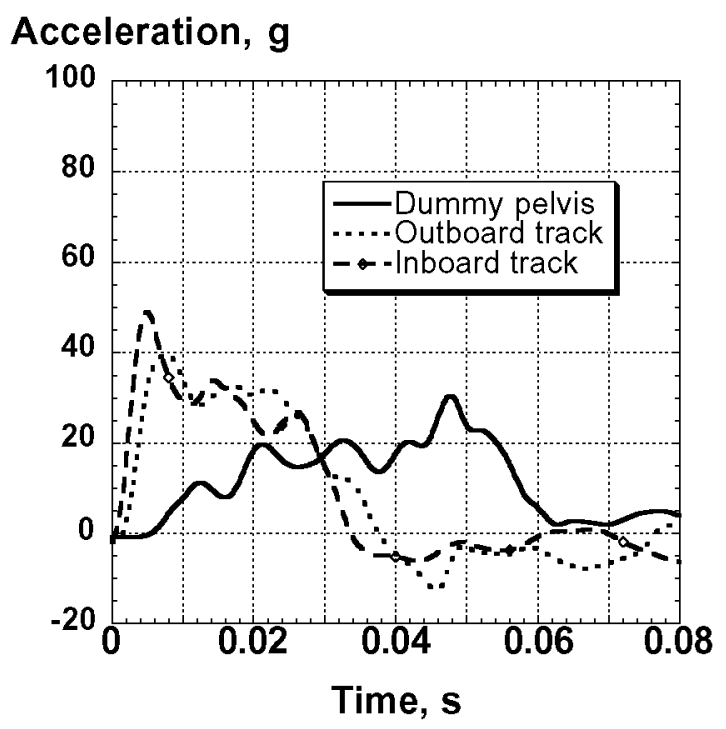

Fig. 10. Comparison of floor-level and left dummy pelvis acceleration.
The lumbar load measured at the base of the spinal column can be used to predict spinal injury. To prevent or limit injury to the spine, FAR Part 27.562c [12] stipulates that the lumbar load should not exceed 1,500 pounds. The lumbar loads for each dummy are plotted in Figure 13. The peak lumbar load measured in the pelvis of the right dummy is slightly less than 1,500 pounds, while the peak load measured in the right dummy pelvis was slightly over 1,500 pounds. Consequently, the objectives of FAR Part 27.562c were met for the right dummy and were almost met for the left dummy.

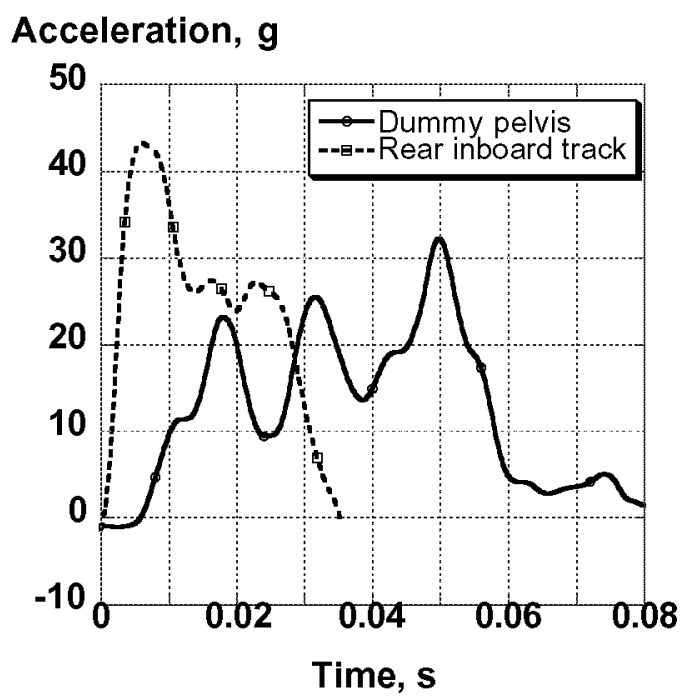

Fig. 11. Comparison of right floor-level and right dummy pelvis acceleration. (180 Hz filter)

Acceleration, $\mathbf{G}$

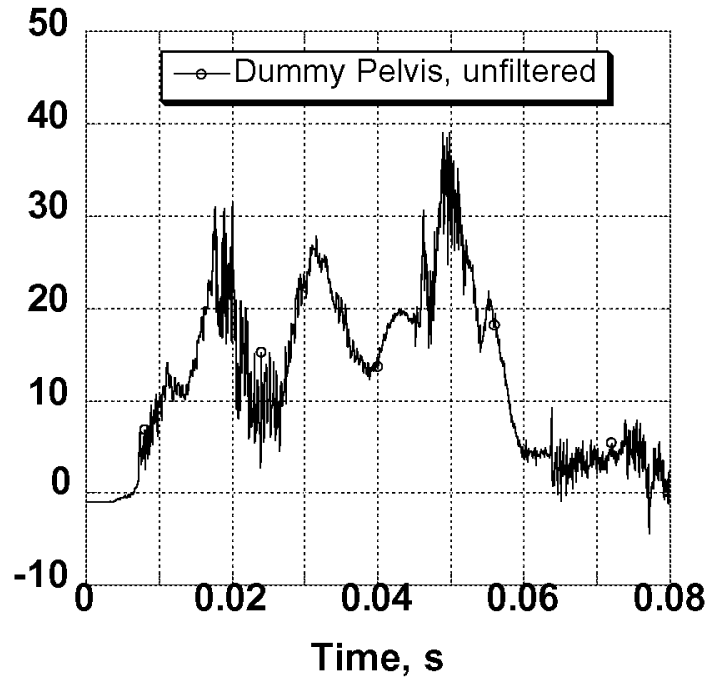

Fig. 12. Right dummy pelvis vertical acceleration, unfiltered. 
The Dynamic Response Index (DRI) model $[13,14]$ is another useful indicator of spinal injury. The DRI model was developed by the Air Force Wright Laboratory to estimate the probability of compression fractures in the lower spine due to acceleration in a pelvis-to-head (eyeballs down) direction, as might be experienced by aircrew during emergency ejection seat operations. The maximum value of the DRI for the left dummy was calculated to be approximately 24 . Operational data from ejection seat incidents indicates a 50 percent chance of a spinal compression fracture for this DRI value [14].

\section{Load, Ibs x 1000}

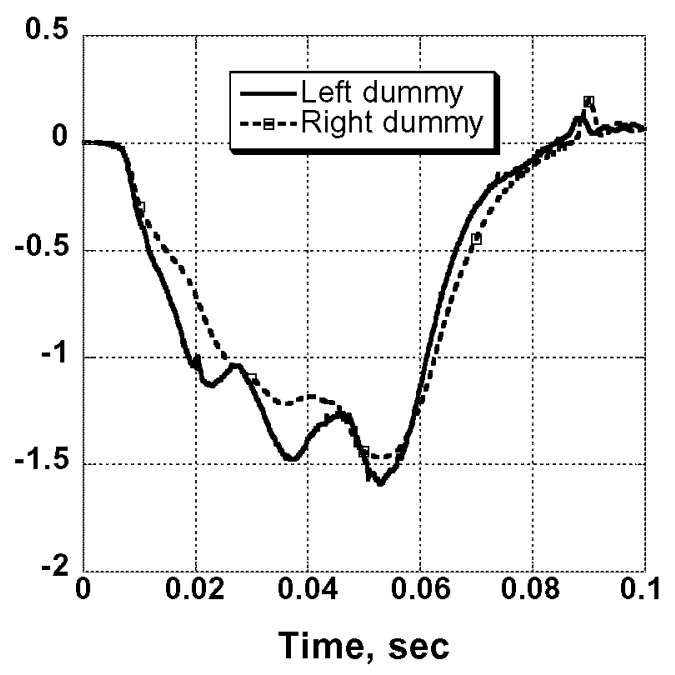

Fig. 13. Left and right dummy lumbar loads, unfiltered.

\section{Analytical and Experimental Correlation}

\section{Fuselage, Seat, and Occupant Response}

Comparisons between test and analysis will first be made with acceleration responses measured on the large lead masses. In Figure 14, the two symmetric rear inboard accelerometers on the 100-1b. lead masses are compared with the model predictions. The left inboard accelerometer exhibits a peak of $50-\mathrm{g}$ while the right inboard acceleration is lower at $43-\mathrm{g}$. In addition, although the model was symmetric, the left and right rear inboard accelerations are not identical. The peaks of the analytical data range from 49-g to 53-g. However, both analytical acceleration pulses exhibit a second peak after 0.02 seconds that is considerably higher than in the experimental data. A comparison of the experimental outboard accelerations with the analytical predictions is shown in Figure 15. In this case, the model predicts the pulse duration well, but over predicts the peak acceleration. The over prediction in acceleration produces a higher model rebound velocity than is observed experimentally. Evidently, more energyabsorbing failure and/or damping mechanisms are active in the actual structure than are modeled in the analysis.
Also, the dynamic crushing strength of the subfloor foam may differ from the quasi-static loading curve shown in figure 6 due to the trapped air inside the foam. In scaled subfloor dynamic tests, fragments of the foam were noted to explosively break away, which did not happen during the quasi-static loading test.

\section{Acceleration, $\mathbf{g}$}

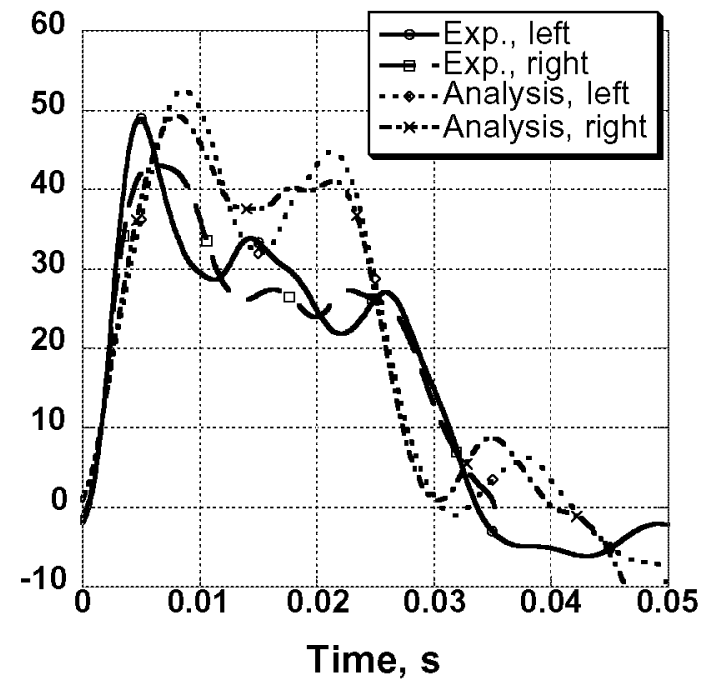

Fig. 14. Comparison of experimental rear inboard accelerations with model results.

\section{Acceleration, $\mathrm{g}$}

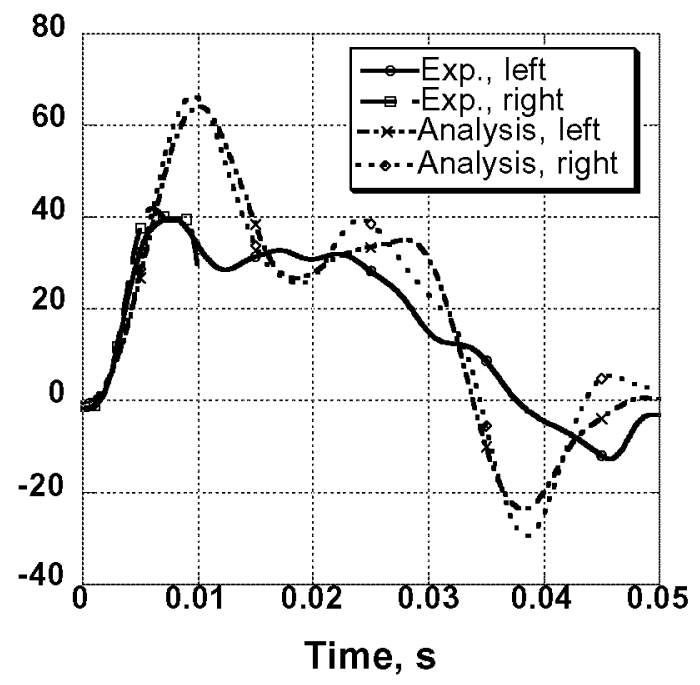

Fig. 15. Comparison of experimental rear outboard accelerations with model results.

The measured front outboard accelerations are compared with analysis in Figure 16 for the lead masses located on the left and right sides of the fuselage floor. The initial 
predicted peak is approximately $38-\mathrm{g}$, which is considerably higher than the measured value of $27-\mathrm{g}$. After 0.015 seconds, the experimental and predicted values are much closer. In Figure 17, the predicted front inboard accelerations are close to the experimental values for the first 0.010 seconds. However, the experimental data is nearly flat with a relative minimum at 0.02 seconds. In contrast, the analysis predicts a relative maximum at 0.02 seconds. Despite these differences, the fundamental pulse width and shape is comparable for both data and analysis.

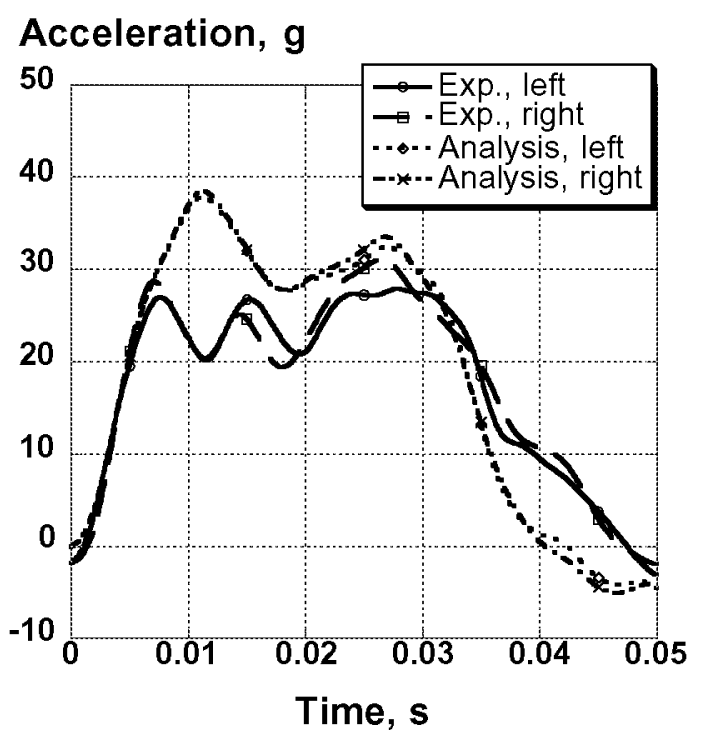

Fig. 16. Comparison of experimental front outboard accelerations with model results.

In Figure 18, the pelvis acceleration of the ATB model is compared with the left dummy pelvis vertical acceleration response. As shown in the figure, the ATB model predicted the overall shape, pulse duration, and maximum acceleration quite well. The predicted peak pelvis acceleration was 24-g, as compared with an experimental acceleration that oscillated about $20 \mathrm{~g}$ for 0.02 seconds before peaking locally at $30-\mathrm{g}$. The maximum acceleration predicted by ATB is $24-\mathrm{g}$ as compared with $30-\mathrm{g}$ measured experimentally.

In contrast to the acceleration responses of the large masses and the dummy occupant, the accelerations measured near the seat legs are much more oscillatory in nature. Consequently, a velocity correlation between test and analysis is shown in Figure 19. Notice that the test and analysis velocities agree quite well for the initial 0.005 seconds. Also notice that the predicted velocity response shows more oscillatory behavior. Both the experimental and the analytical data indicate that the velocity goes to zero before 0.03 seconds. The experimental velocity does not indicate much rebound after crossing zero, whereas the analytical velocity rebounds to a maximum of about $70 \mathrm{in} / \mathrm{s}$. Now that the velocity trace for the floor has been examined, the next step is to examine the seat leg floor accelerations in Figures 20 and 21. As might be expected, the initial peak acceleration is well matched. However after the first peak, the agreement is not as well defined.

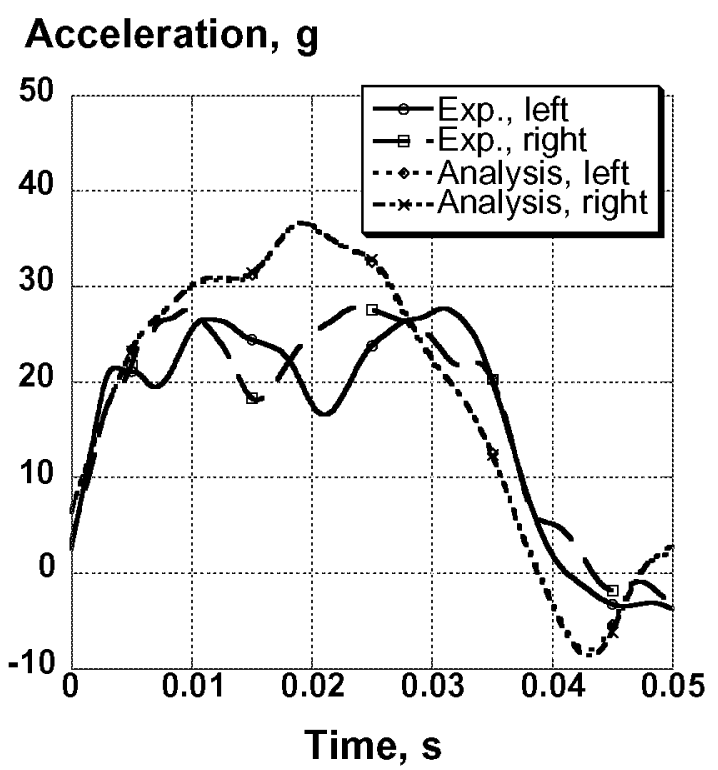

Fig. 17. Comparison of experimental front inboard accelerations with model results

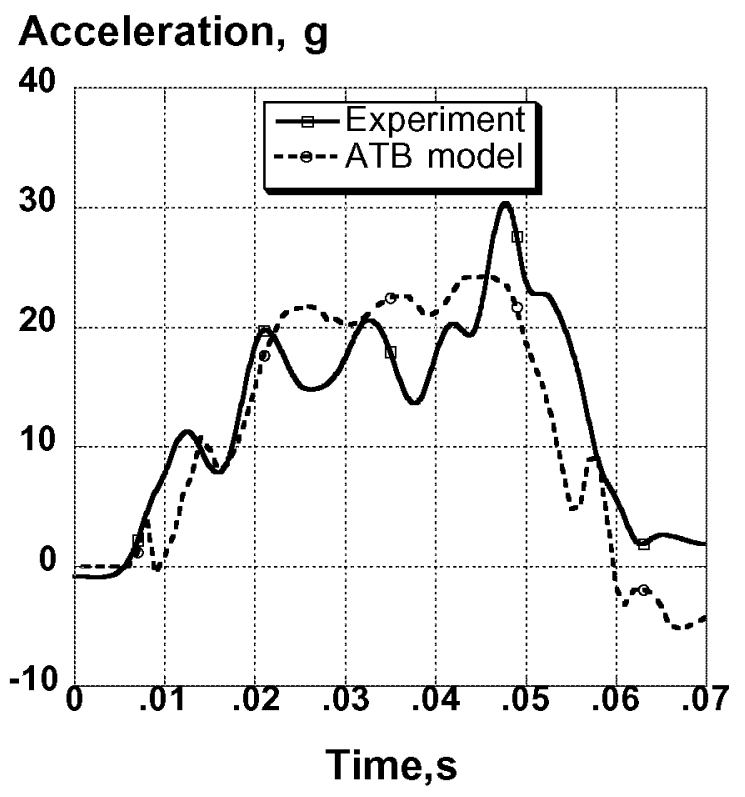

Fig. 18. Measured left dummy pelvis vertical acceleration compared with the Dytran/ATB predicted pelvis acceleration.

\section{Structural Deformation}

Motion picture data selected from frames taken at approximately 0.0025 -second intervals (400 frames/second) are compared with the model behavior in Figures 22 and 23. The motion picture data show that the front end of 
the section impacted with less than one-degree downward pitch. This initial pitch angle was not included in the model. The front view shows that the dummy and seat models follow the actual motion quite well. Since the section was initially pitched front-end down by almost one degree, the crushing of the subfloor in the front view of the model does not exactly match the actual crushing.

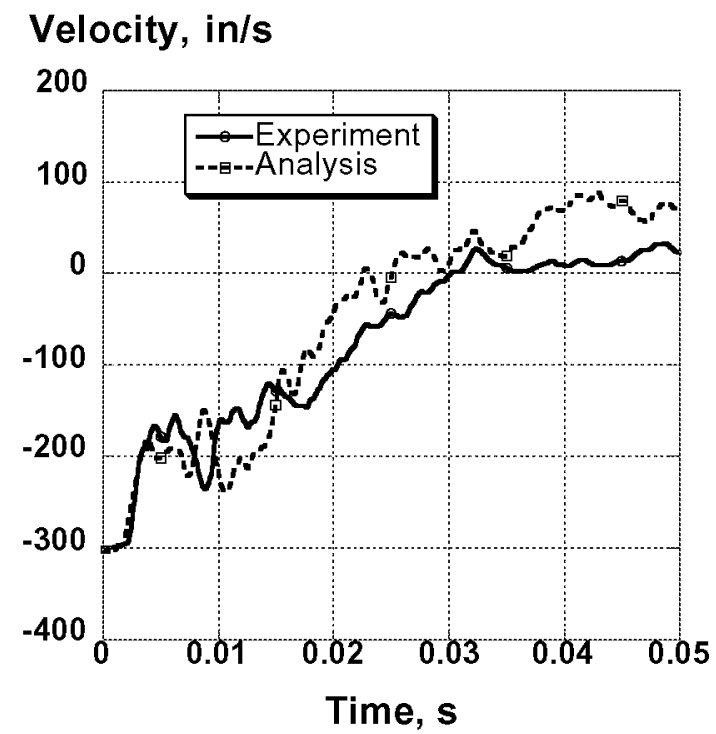

Fig. 19. Left seat front outboard floor seat leg velocity from integrated acceleration compared with analysis.

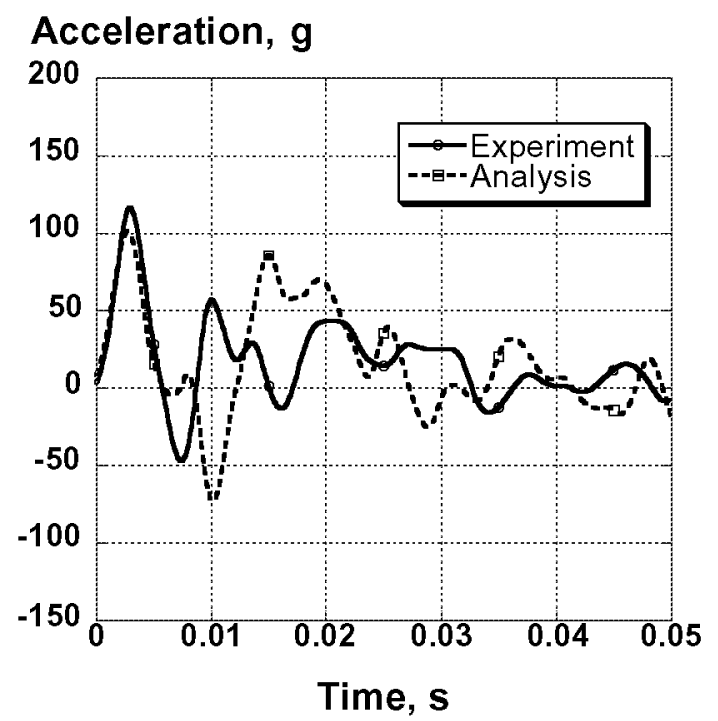

Fig. 20. Acceleration time-history for the bottom of outboard front seat leg of the left seat.

The comparison of the side-view camera frames with the predicted motion is shown in Fig. 23. Note that both the test and model show the front of the section pitched down by 4 degrees at 0.05 seconds. Also, by 0.07 seconds, the section is approximately level again. The center of gravity of the section and model were both located longitudi- nally in the center. The front-end downward pitch is caused by the action of the seats and dummies. Since the load path of the dummies is through the crushable energyabsorbing seats, which are actually load-limiting devices, the downward force applied to the floor by the seat legs is lower than if a rigid seat had been used. Consequently, since the seats and dummies are behind the center-ofgravity, a counter-clockwise pitching moment results.

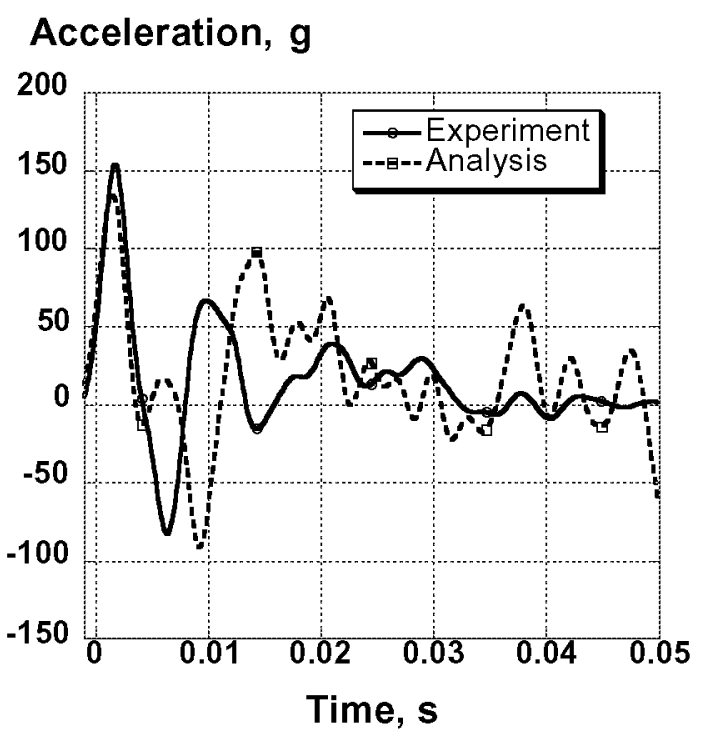

Fig. 21. Acceleration time-history for the bottom of inboard front seat leg of the left seat.

The motion of the seat can be seen in both the front and side views in Figures 22 and 23, respectively. In the front view, one can observe the two rear side braces of the seat bending outward. At time $\mathrm{t}=0.07$ seconds the seat has essentially bottomed out and the dummies are very close to the floor. Close-up pictures of the right JAARS seat taken post-test are shown in Figure 24. The deformation of the S-shaped front seat legs and the support strap can be clearly seen in the pictures. The front frames of the JAARS seats were originally 10 inches above the floor, while the rear horizontal seat frames were 9.5 inches above the floor. After the test, the permanently-deformed corners of the front seat measured from 5.15- to 5.6inches above the floor, while the rear frame corners measured from 6.875- to 7.65-inches above the floor. Thus the front of the frame stroked about 5 inches for the right seat and about 4.5 inches for the left seat, while the back of the right seat stroked about 2.5 inches and the back of the left seat stroked about 2.0 inches. Recall from an examination of the lumbar load curves in Figure 13, that the dummy in the right seat did experience a smaller peak lumbar load, which is consistent with the seat stroking data. 

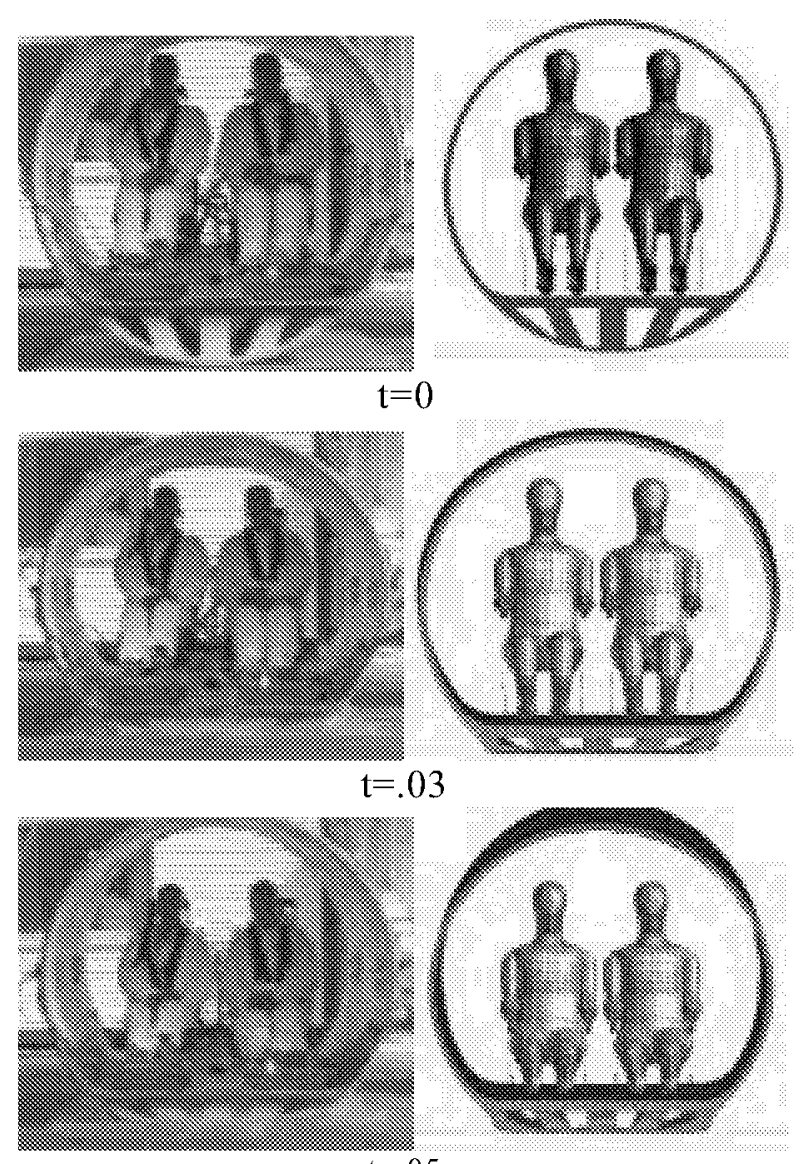

$\mathrm{t}=.05$

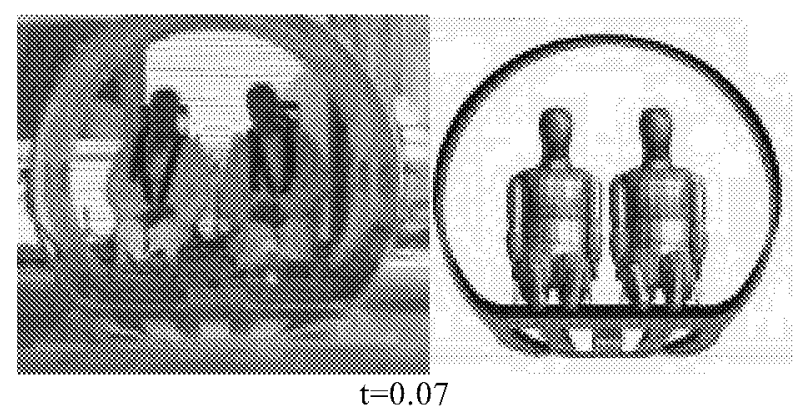

Fig. 22. Front view comparison of high-speed film data with model.
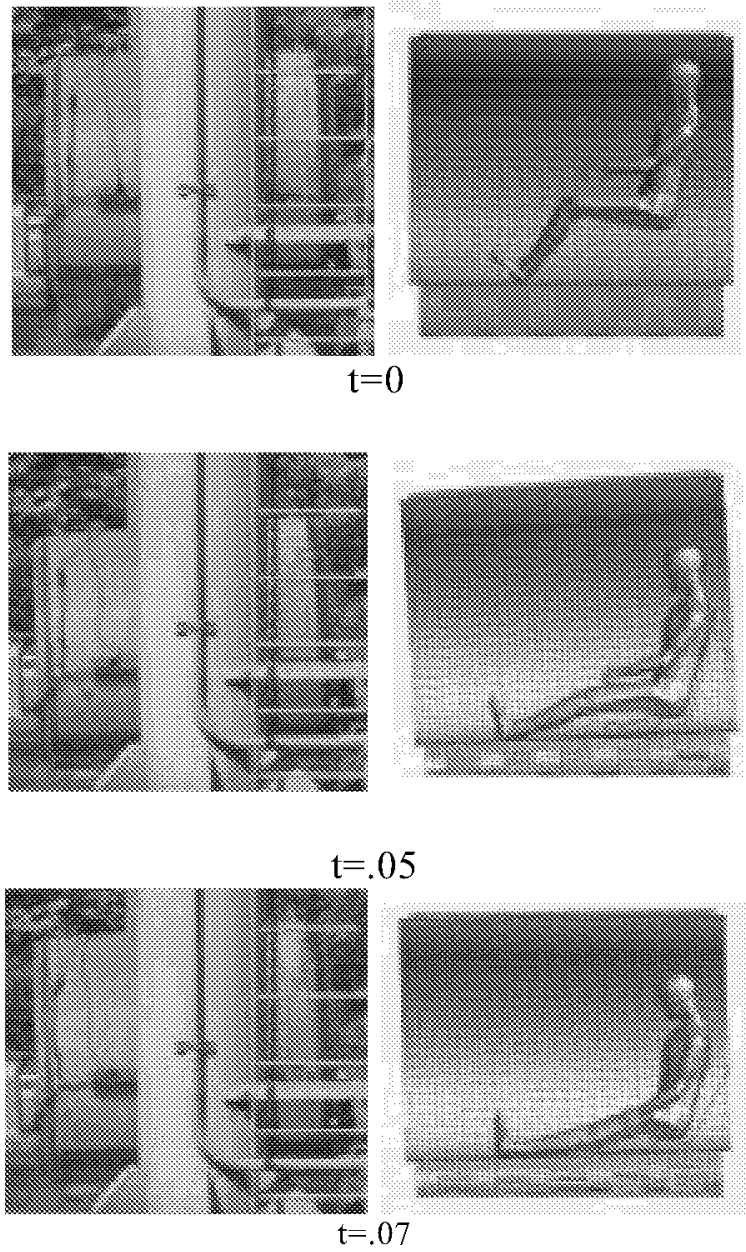

Fig. 23. Side view comparison of high-speed video film data with model.


Fig. 24. Deformed JAARS seats, post-test. 


\section{Concluding Remarks}

A $25-\mathrm{ft} / \mathrm{s}$ vertical drop test of an innovative composite fuselage section was conducted to evaluate its crash performance under a more realistic loading environment with seats and dummies. The fuselage design had been validated previously in vertical drop tests in which lead weights were used to represent the inertial properties of seats and occupants. The fuselage section consists of a relatively rigid upper compartment (passenger cabin) with a stiff structural floor and a lower energy-absorbing foamfilled subfloor. Two JAARS load-limiting seats were mounted to seat rails on the floor of the fuselage section and two 50th percentile male Hybrid II anthropomorphic dummies were secured in the seats using conventional lap belt restraint systems. Additional lead weights were attached to the seat rails to bring the total floor loading to approximately $1,000 \mathrm{lbs}$. The total weight of the fully instrumented fuselage section with seats and dummies was $1,243 \mathrm{lbs}$.

The fuselage section, seats, and dummies were instrumented with 80 transducers to record the dynamic response during the impact. The test dummies were instrumented with lumbar load cells to measure spinal compressive loads. The dummies were instrumented with tri-axial accelerometers located in the head, chest, and pelvis. Additional accelerometers were mounted to the floor masses, the seat pans, and the fuselage structure. The data were recorded at 10,000 samples/second using a digital data acquisition system. Test data and motion picture analysis of the high-speed film indicate that the fuselage section impacted with less than one-degree pitch, such that the front edge of the section hit the impact surface first. The experimental inboard floor-level acceleration responses were, in general, of higher magnitude and shorter duration than the outboard responses. Peak floorlevel acceleration ranged from 28 - to $48-\mathrm{g}$. The dummy pelvic acceleration responses were of lower magnitude $(20-\mathrm{g})$ and longer duration than the floor-level responses. The measured lumbar load in the left dummy slightly exceeded the 1,500-lb. injury threshold, whereas the lumbar load of the right dummy was slightly lower than $1,500 \mathrm{lbs}$.

A crash simulation of the vertical drop test was developed using the nonlinear, explicit transient dynamic finite element code, MSC.Dytran. A finite element model of the fuselage structure, seat rails, and seats was developed for the simulation. The Rohacell foam blocks used in the energy-absorbing subfloor were modeled with the FOAM2 material property available in MSC.Dytran. This material model is used to represent a crushable, isotropic material with a user-specified crush response, energy dissipation factor and unloading curve, and with a Poisson's ratio that is effectively zero. The anthropomorphic dummies were represented using the human occupant simulation code, Articulated Total Body (ATB), which is integrated into the MSC.Dytran code. The ATB dummy model consists of hinged segments with inertial proper- ties, joints, and contact surfaces defined to represent a Hybrid II male dummy. The ATB dummy segments are covered with rigid shell elements in MSC.Dytran to provide the correct body contour needed for contact definitions.

The analytical and experimental correlation results were presented for the floor-level acceleration and occupant responses. In general, the finite element simulation predicted the overall shape, magnitude, and pulse duration of the large mass items on the floor. It is evident that a higher rebound velocity is observed in the model than is seen experimentally indicating that more energy-absorbing and/or damping mechanisms are active in the actual structure than are included in the model. Excellent prediction of the overall shape of the dummy pelvic acceleration response was obtained. The predicted peak pelvis acceleration was $24-\mathrm{g}$, as compared with an experimental acceleration that oscillated about 20 -g for 0.02 seconds before peaking locally at $30-\mathrm{g}$. Finally, the model deformation was correlated with frames taken from the high-speed film. These results indicate that the overall seat deformation and occupant motion trends were well predicted. In addition, the simulation captured the 4 degree front-down pitching motion of the fuselage that occurred at time 0.05 seconds after impact.

\section{References}

1. Jackson, K. E., "A Comparative Analysis of Three Composite Fuselage Concepts for Crash Performance," 52nd American Helicopter Society Forum and Technology Display, Washington DC, June 4-6, 1996.

2. Jackson, K. E., "Analytical Crash Simulation of Three Composite Fuselage Concepts and Experimental Correlation," Journal of the American Helicopter Society, Vol. 42, No. 2, April 1997, pp. 116-125.

3. Jackson, K. E., and Fasanella, E. L., "Innovative Composite Fuselage Design for Improved Crashworthiness," 54th American Helicopter Society Forum and Technology Display, Washington D C, May 20-22, 1998.

4. Fasanella, E. L., and Jackson, K. E., "Analytical and Experimental Evaluation of Composite Energy-Absorbing Subfloor Concepts," American Helicopter Society National Technical Specialists' Meeting on Rotorcraft Crashworthiness, Phoenix, AZ, September 14-17, 1998.

5. Jackson, K. E., and Fasanella, E. L. "Crashworthy Evaluation of a 1/5-Scale Model Composite Fuselage Concept," $55^{\text {th }}$ American Helicopter Society Annual Forum and Technology Display, Montreal, Canada, May 2527, 1999.

6. Jackson, Karen E., Fasanella, Edwin L, and Knight, Jr., Norman F., "Demonstration of a Crashworthy Composite Fuselage Concept." Proceedings of the $22^{\text {nd }}$ Army 
Science Conference, Baltimore, MD, December 11-13, 2000 .

7. Lyle, K. H., Bark, L. W., and Jackson, K. E., "Evaluation of Test/Analysis Correlation Methods for Crash Applications," Proceedings of the 57th American Helicopter Society Annual Forum, Washington D.C., May 9-11, 2001.

8. Sareen, A. K., Fasanella, E. L., Sparks, C., Jackson, K. E., and Mullins, B. R., "Comparison of Soft Soil and Hard Surface Impact Performance of a Crashworthy Composite Fuselage Concept," AHS Forum 58 Proceedings, Montreal, Canada, June 11-13, 2002.

9. MSC.Dytran User's Manual Version 4.7, Volumes 1 and 2. MSC Software Corporation, Los Angeles, CA, 1999.

10. Obergefell, L. A., Gardner, T. R., Kaleps, I., and Fleck, J. T., Articulated Total Body Model Enhancements, Volume 2: User's Guide. AAMRL-TR-88-043, January 1988.

11. Williams, M. Susan and Fasanella, E. L., "Crash Tests of Four Low-Wing Twin-Engine Airplanes with Truss- Reinforced Fuselage Structure." NASA TP 2070, 1982.

12. Code of Federal Regulations, Federal Aviation Regulations for Aviation Maintenance Technicians FAR AMT, Part 27 Airworthiness Standard: Normal Category Rotorcraft, 27.562 Emergency Landing Dynamics.

13. Stech, E. L. and P. R. Payne, "Dynamic Models of the Human Body," AAMRL-TR-66-157, Aerospace

Medical Research Laboratory, Wright-Patterson Air Force Base, Ohio, 1969.

14. Brinkley, J. W., and Shaffer, J. T., "Dynamic Simulation Techniques for the Design of Escape Systems: Current Applications and Future Air Force Requirements," Aerospace Medical Research Laboratory; AMRL Technical Report 71-292, Wright-Patterson Air Force Base, Ohio, December 1971, AD 740439. 


\begin{tabular}{|c|c|c|c|c|}
\hline \multicolumn{3}{|c|}{ REPORT DOCUMENTATION PAGE } & \multicolumn{2}{|r|}{$\begin{array}{l}\text { Form Approved } \\
\text { OMB No. 0704-0188 }\end{array}$} \\
\hline \multicolumn{5}{|c|}{$\begin{array}{l}\text { Public reporting burden for this collection of information is estimated to average } 1 \text { hour per response, including the time for reviewing instructions, searching existing data sources, } \\
\text { gathering and maintaining the data needed, and completing and reviewing the collection of information. Send comments regarding this burden estimate or any other aspect of this } \\
\text { collection of information, including suggestions for reducing this burden, to Washington Headquarters Services, Directorate for Information Operations and Reports, } 1215 \text { Jefferson } \\
\text { Davis Highway, Suite 1204, Arlington, VA 22202-4302, and to the Office of Management and Budget, Paperwork Reduction Project (0704-0188), Washington, DC 20503. }\end{array}$} \\
\hline 1. AGENCY USE ONLY (Leave blank) & $\begin{array}{l}\text { 2. REPORT DATE } \\
\text { June } 2002\end{array}$ & \multicolumn{3}{|c|}{$\begin{array}{l}\text { 3. REPORT TYPE AND DATES COVERED } \\
\text { Technical Memorandum }\end{array}$} \\
\hline \multicolumn{3}{|c|}{$\begin{array}{l}\text { 4. TITLE AND SUBTITLE } \\
\text { Impact Testing and Simulation of a Crashworthy Composite Fuselage Sec- } \\
\text { tion With Energy-Absorbing Seats and Dummies }\end{array}$} & \multirow{2}{*}{\multicolumn{2}{|c|}{$\begin{array}{l}\text { 5. FUNDING NUMBERS } \\
\text { WU 728-50-10-01 }\end{array}$}} \\
\hline \multicolumn{3}{|l|}{$\begin{array}{l}\text { 6. AUTHOR(S) } \\
\text { Edwin L. Fasanella } \\
\text { Karen E. Jackson }\end{array}$} & & \\
\hline \multicolumn{3}{|c|}{ 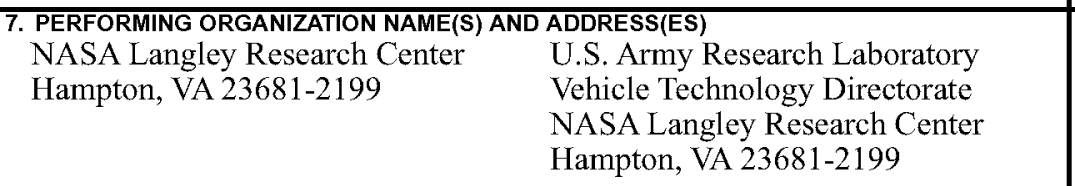 } & \multicolumn{2}{|c|}{$\begin{array}{l}\text { 8. PERFORMING ORGANIZATION } \\
\text { REPORT NUMBER } \\
\text { L-18190 }\end{array}$} \\
\hline \multicolumn{2}{|c|}{$\begin{array}{l}\text { 9. SPONSORING/MONITORING AGENCY NAME(S) AND ADDRESS(ES) } \\
\text { National Aeronautics and Space Administration } \\
\text { Washington, DC 20546-0001 } \\
\quad \text { and } \\
\text { U.S. Army Research Laboratory } \\
\text { Adelphi, MD 20783-1145 }\end{array}$} & & \multicolumn{2}{|c|}{$\begin{array}{l}\text { 10. SPONSORING/MONITORING } \\
\text { AGENCY REPORT NUMBER } \\
\text { NASA/TM -2002-211731 } \\
\text { ARL-TR-2734 }\end{array}$} \\
\hline \multicolumn{5}{|c|}{$\begin{array}{l}\text { 11. SUPPLEMENTARY NOTES } \\
\text { Fasanella and Jackson: ARL, Vehicle Technology Directorate, Langley Research Center, Hampton, VA. Presented } \\
\text { at the AHS International - The Vertical Flight Society's 58th Annual Forum and Technology Display, June 11-13, } \\
\text { 2002, Montreal, Canada. }\end{array}$} \\
\hline \multicolumn{3}{|c|}{$\begin{array}{l}\text { 12a. DISTRIBUTION/AVAILABILITY STATEMENT } \\
\begin{array}{l}\text { Unclassified-Unlimited } \\
\text { Subject Category 05 }\end{array} \\
\begin{array}{l}\text { Availability: NASA CASI (301) } \\
621-0390\end{array}\end{array}$} & \multicolumn{2}{|c|}{ 12b. DISTRIBUTION CODE } \\
\hline \multicolumn{5}{|c|}{$\begin{array}{l}\text { interaction with the seats and dummies. The } 5 \text {-ft. di } \\
\text { energy-absorbing subfloor constructed of Rohacel f } \\
\text { and correlated with predictions from a crash simuli } \\
\text { computer code, MSC.Dytran. The anthropomorph } \\
\text { (ATB) code, which is integrated into MSC.Dytran. }\end{array}$} \\
\hline \multirow{2}{*}{\multicolumn{4}{|c|}{$\begin{array}{l}\text { 14. SUBJECT TERMS } \\
\text { Crashworthiness, air safety, impact dynamics, MSC.Dytran, energy-absorbing seats, } \\
\text { seat and occupant modeling }\end{array}$}} & \begin{tabular}{|l} 
15. NUMBER OF PAGES \\
17 \\
\end{tabular} \\
\hline & & & & 16. PRICE CODE \\
\hline $\begin{array}{l}\text { 17. SECURITY CLASSIFICATION } \\
\text { OF REPORT } \\
\text { Unclassified }\end{array}$ & $\begin{array}{l}\text { 18. SECURITY CLASSIFICATION } \\
\text { OF THIS PAGE } \\
\text { Unclassified }\end{array}$ & $\begin{array}{l}\text { 19. SECURITY CLASSII } \\
\text { OF ABSTRACT } \\
\text { Unclassified }\end{array}$ & FICATION & $\begin{array}{l}\text { 20. LIMITATION } \\
\text { OF ABSTRACT } \\
\text { UL }\end{array}$ \\
\hline NSN 7540-01-280-5500 & & & & $\begin{array}{l}\text { Standard Form } 298 \text { (Rev. 2-89) } \\
\text { Prescribed by ANSI Std. Z39-18 } \\
298-102\end{array}$ \\
\hline
\end{tabular}

